Revista Brasileira de Farmacognosia Brazilian Journal of Pharmacognosy 22(3): 528-533, May/Jun. 2012

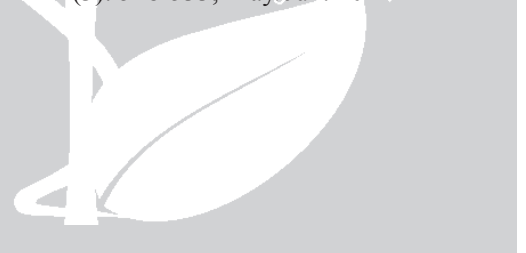

Article

Received 19 Feb 2011

Accepted 22 Oct 2011

Available online 24 Jan 2012

Keywords:

biodiversity

Chagas

cytotoxicity

disease

strains

trypanocidal activity

Trypanosoma cruzi

ISSN 0102-695X

http://dx.doi.org/10.1590/S0102-

695X2012005000014

\section{Trypanocidal activity of Brazilian plants against epimastigote forms from $Y$ and Bolivia strains of Trypanosoma cruzi}

\author{
Renata Tomé Alves, ${ }^{, 1}$ Luis Octávio Regasini, ${ }^{2}$ Cristiano \\ Soleo Funari, ${ }^{2}$ Maria Cláudia Marx Young, ${ }^{3}$ Aline Rimoldi, ${ }^{4}$ \\ Vanderlan da Silva Bolzani, ${ }^{2}$ Dulce Helena Siqueira Silva, ${ }^{2}$ \\ Sérgio de Albuquerque, ${ }^{5}$ João Aristeu da Rosa ${ }^{1}$
}

\author{
${ }^{1}$ Laboratório de Parasitologia, Faculdade de Ciências Farmacêuticas de \\ Araraquara-SP, Universidade Estadual Paulista, Brazil, \\ ${ }^{2}$ Departamento de Química Orgânica, Instituto de Química de Araraquara-SP, \\ Universidade Estadual Paulista, Brazil, \\ ${ }^{3}$ Instituto de Botânica de São Paulo, Brazil, \\ ${ }^{4}$ Instituto de Biologia, Universidade Estadual de Campinas-SP, Brazil, \\ ${ }^{5}$ Laboratório de Parasitologia, Faculdade de Ciências Farmacêuticas de Ribeirão \\ Preto-SP, Universidade de São Paulo, Brazil.
}

\begin{abstract}
Chagas disease is one of the main public health problems in Latin America. Since the available treatments for this disease are not effective in providing cure, the screening of potential antiprotozoal agents is essential, mainly of those obtained from natural sources. This study aimed to provide an evaluation of the trypanocidal activity of 92 ethanol extracts from species belonging to the families Annonaceae, Apiaceae, Cucurbitaceae, Lamiaceae, Lauraceae, Moraceae, Nyctaginaceae, and Verbenaceae against the $\mathrm{Y}$ and Bolivia strains of Trypanosoma cruzi. Additionally, cytotoxic activity on LLCMK2 fibroblasts was evaluated. Both the trypanocidal activity and cytotoxicity were evaluated using the MTT method, in the following concentrations: 500, 350, 250, and $100 \mu \mathrm{g} / \mathrm{mL}$. Benznidazole was used for positive control. The best results among the 92 samples evaluated were obtained with ethanol extracts of Ocotea paranapiacabensis (Am93) and Aegiphila lhotzkiana (Am160). Am93 showed trypanocidal activity against epimastigote forms of the Bolivia strain and was moderately toxic to LLCMK2 cells, its Selectivity Index (SI) being 14.56, while Am160 showed moderate trypanocidal activity against the Bolivia strain and moderate toxicicity, its SI being equal to 1.15. The screening of Brazilian plants has indicated the potential effect of ethanol extracts obtained from Ocotea paranapiacabensis and Aegiphila lhotzkiana against Chagas disease.
\end{abstract}

\section{Introduction}

In Latin America, Chagas disease is an important cause of morbidity, affecting around 10 million people and representing a risk for 25 million from the South of the United States to the South of Argentina (WHO, 2010).

Since this disease affects mostly poor populations, the development of new therapeutic solutions is not an attractive business for the large pharmaceutical companies, and currently it can be said that this initiative is being extremely neglected, which is a very concerning fact on account of the needs of those people (Nwaka \& Ridley, 2003). The two drugs available for the treatment of Chagas disease, nifurtimox and benznidazole, have potential toxic side effects and variable efficiency, both of them being ineffective in eradicating the infection during its chronic phase, which contributes to its low use rates (Coura, 2009). For this reason, the screening of potential new compounds is essential (Coura \& Castro, 2002).

The difficulty to find a substance capable of fighting the parasite can be directly related to the morphological characteristics of the strain, mainly considering the presence of different populations, which present distinct tissue tropism. Therefore, different strain groups of T. cruzi should be considered in the evaluation of new drugs (Macedo et al., 2002).

This scenario clearly shows that it is necessary to develop therapies that stop the multiplication of T. cruzi without causing any severe side effect (Coura \& Castro, 2002). Medicinal plants have been used in the treatment for parasitic diseases for a long time, and many works 
sustain the therapeutic value of products from plant origin, also describing the trypanocidal activity of natural active compounds (Bastos et al., 1999; Saraiva et al., 2007; Batista Jr. et al., 2008).

Continuing our studies on the discovery of trypanocidal agents obtained from plants from both the Cerrado and the Atlantic Forest (Cotinguiba et al. 2009; Lopes et al., 2008; Regasini et al. 2009), 92 ethanol extracts of species belonging to the families Annonaceae, Apiaceae, Cucurbitaceae, Lamiaceae, Lauraceae, Moraceae, Nyctaginaceae, and Verbenaceae were tested against epimastigote forms of Trypanosoma cruzi (Y and Bolivia strains), and their cytotoxic activity on LLCMK $_{2}$ fibroblasts was evaluated. The emergency to find new antiprotozoal agents with trypanocidal activity and the evidence that some species of the aforementioned families have trypanocidal activity against parasitic forms of $T$. cruzi provided the motivation to carry out the screening of such extracts (Buainain et al., 1992; Fournet et al., 2007; Osorio et al., 2007; Cabral et al., 2010).

\section{Material and methods}

\section{Parasites}

In the assays both the $\mathrm{Y}$ and Bolivia strains were used, the former belonging to lineage I and the latter, to lineage II. The strains were kept in BALB/c mices and in LIT (Liver Infusion Tryptose) culture medium, in BOD incubator at $28{ }^{\circ} \mathrm{C}$, at the Laboratory of Parasitology of the Faculty of Pharmaceutical Sciences of Araraquara-SP, Unesp.

\section{Plant material and extraction}

The plant material was collected by Maria Cláudia Marx Young in remaining areas of Atlantic Forest and Cerrado in the State of São Paulo, and it was identified by Inês Cordeiro, Institute of Botany, State Department of the Environment, São Paulo-SP. The voucher specimens were then deposited in the herbarium "Maria Eneyda P. Kaufmann" at the IBT-SMA. The codes of the extracts and voucher specimens can be found in Table 1.

After the collection, the botanical material was dried in the absence of light and then powdered using a cutting mill. A $30 \mathrm{~g}$ portion of the powder was extracted with ethanol $(5 \times 100 \mathrm{~mL})$ during three weeks, at room temperature. After the filtration, the solvent was evaporated under reduced pressure, which resulted in the crude extracts.

Twenty-eight of the 92 ethanol extracts evaluated belong to the genera Rollinia, Xylopia, Anaxagorea, Annona, Guatteria and Duguetia, family Annonaceae; one to the genus Hydrocotyle, family Apiaceae; two to the genus Cayaponia, family Cucurbitaceae; two to the genera
Aegiphila, family Lameaceae 36 to the genera Nectandra and Ocotea, family Lauraceae; one to the genus Dorstenia, family Moraceae; eight to the genera Bougainvilleae, Pisonia and Guapira, family Nyctaginaceae; and fourteen to the genera Lantana, Starchytarpheta, and Lippia, family Verbenaceae (Table 1).

\section{In vitro assay for trypanocidal activity}

Trypanocidal activity was evaluated by means of the MTT method, with changes (Muelas-Serrano et al., 2000).

The epimastigote forms $\left(1.10^{7}\right.$ parasites $\left./ \mathrm{mL}\right)$, obtained from culture in stationary phase, were cultured in plates with 96 wells in BOD incubator at $28^{\circ} \mathrm{C}$ for 24 $\mathrm{h}$, concentrations for the ethanol extracts being 500,350 , 250 and $100 \mu \mathrm{g} / \mathrm{mL}$. After this period, the MTT $(2.5 \mathrm{mg} /$ $\mathrm{mL})$ and PMS $(0.22 \mathrm{mg} / \mathrm{mL})$ solutions were added to each well, and the plate was incubated for $1 \mathrm{~h}$. Then $100 \mu \mathrm{L}$ of $\mathrm{HCl}(1 \mathrm{M})$ and SDS (10\%) were added to it. The plate was kept at room temperature for $30 \mathrm{~min}$, and the reading was performed on a spectrophotometer at $595 \mathrm{~nm}$. Benznidazole was used in the same concentrations for positive control.

The assays were in triplicate, and the results were expressed as IC50, calculated by the statistical method of sigmoid concentration-response curve using the GraphPad Prisma 4.0 software.

\section{Cytotoxicity assay}

Extracts with trypanocidal activity against epimastigote forms of $T$. cruzi were evaluated regarding their cytotoxicity on LLCMK2 fibroblasts by means of the MTT method, with changes (Muelas-Serrano et al., 2000).

LLCMK $_{2}$ cells $\left(1.10^{6} / \mathrm{mL}\right)$ were cultured in plates with 96 wells and ethanol extracts in the following concentrations: 500, 350, 250 and $100 \mu \mathrm{g} / \mathrm{mL}$. The plates were incubated in a $\mathrm{CO}_{2}$ incubator at $5 \%$ and $37{ }^{\circ} \mathrm{C}$ for $24 \mathrm{~h}$. After that period, $10 \mu \mathrm{L}$ of MTT solution $(5 \mathrm{mg} / \mathrm{mL})$ were added to each well, and the plates were incubated for $4 \mathrm{~h}$. Then $100 \mu \mathrm{L}$ of acid isopropyl were added, and the plate was kept at room temperature for $1 \mathrm{~h}$. The reading was performed on a spectrophotometer at $595 \mathrm{~nm}$. RPMI culture medium was used for positive control, whereas $\mathrm{LLCMK}_{2}$ cells were used for negative control.

The assays were carried out in triplicate, and the results were expressed as CC50, calculated by the statistical method of sigmoid concentration-response curve using the GraphPad Prisma 4.0 software.

The cytotoxic activity (CC50) was related to the trypanocidal activity (IC50) in order to determine the correspondent Selectivity Index (IS=CC50/IC50). 
Trypanocidal activity of Brazilian plants against epimastigote forms from $\mathrm{Y}$ and Bolivia strains of Trypanosoma cruzi

Table 1. Ethanol extracts of plants from the Atlantic Forest and Cerrado.

\begin{tabular}{|c|c|c|c|c|c|}
\hline $\begin{array}{l}\text { Extract/voucher } \\
\text { sample }\end{array}$ & Species & Part of the plant & Extract/voucher sample & Species & Part of the plant \\
\hline \multicolumn{6}{|c|}{ Annonaceae } \\
\hline M723 & Rollinea sericea & Branches & Rm98 & Xylopia langsdorfiana & Leaves \\
\hline M1103 & Xylopia aromatica & Fruits & Rm99 & Xylopia langsdorfiana & Branches \\
\hline M1143 & Anaxagorea dolichocarpa & Leaves & $\mathrm{Am} 03$ & Guatteria elliptica & Branches \\
\hline M1144 & Anaxagorea dolichocarpa & Branches & Am115 & Rollinea sericea & Branches \\
\hline R123 & Annona cacans & Leaves & Am145 & Duguetia furfuracea & Leaves \\
\hline R124 & Annona cacans & Branches & Am146 & Duguetia furfuracea & Branches \\
\hline $\mathrm{R} 278$ & Guatteria australis & Leaves & $\operatorname{Am} 223$ & Annona coriacea & Leaves \\
\hline $\mathrm{R} 279$ & Guatteria australis & Branches & $\operatorname{Am} 224$ & Annona coriacea & Branches \\
\hline $\mathrm{R} 286$ & Xylopia aromatica & Leaves & Am338 & Guatteria nigrescens & Leaves \\
\hline $\mathrm{R} 287$ & Xylopia aromatica & Branches & Am339 & Guatteria nigrescens & Branches \\
\hline R316 & Duguetia furfuracea & Fruits & $\mathrm{Am} 352$ & Duguetia lanceolata & Leaves \\
\hline R404 & Annona cornifolia & Leaves & Am379 & Duguetia lanceolata & Branches \\
\hline R405 & Annona cornifolia & Branches & Am468 & Guatteria elliptica & Leaves \\
\hline $\mathrm{Rm} 12$ & Rollinea sericea & Leaves & Am469 & Guatteria elliptica & Branches \\
\hline \multicolumn{3}{|c|}{ Apiaceae } & \multicolumn{3}{|c|}{ Lamiaceae } \\
\hline M 861 & Hydrocotyle banariensis & Leaves & Am 158 & Aegiphila lhotzkiana & Leaves \\
\hline \multicolumn{3}{|c|}{ Cucurbitaceae } & Am159 & Aegiphila lhotzkiana & Branches \\
\hline Am 109 & Cayaponia tayiuya & Fruits & Am 160 & Aegiphila lhotzkiana & Fruits \\
\hline Am 110 & Cayaponia tayiuya & Branches & $\mathrm{R} 184$ & Aegiphila sellowiana & Leaves \\
\hline Am 109 & Cayaponia tayiuya & Fruits & $\mathrm{R} 185$ & Aegiphila sellowiana & Branches \\
\hline \multicolumn{6}{|c|}{ Lauraceae } \\
\hline M686 & Nectandra oppositifolia & Leaves & $\mathrm{R} 173$ & Ocotea velutina & Branches \\
\hline M687 & Nectandra grandiflora & Leaves & $\mathrm{R} 188$ & Ocotea silvestris & Leaves \\
\hline M698 & Nectandra grandiflora & Branches & R189 & Ocotea silvestris & Branches \\
\hline M819 & Nectandra membracea & Leaves & R388 & Ocotea megabotamica & Leaves \\
\hline R174 & Nectandra aspidata & Leaves & R389 & Ocotea megabotamica & Branches \\
\hline $\mathrm{R} 175$ & Nectandra aspidata & Branches & R429 & Ocotea pulchella & Leaves \\
\hline $\mathrm{Rm} 128$ & Nectandra membranaceae & Leaves & $\mathrm{R} 430$ & Ocotea pulchella & Branches \\
\hline Am12 & Nectandra cissiflora & Branches & Am71 & Ocotea laxa & Leaves \\
\hline Am46 & Nectandra membranaceae & Branches & Am72 & Ocotea laxa & Branches \\
\hline Am 257 & Nectandra cuspidata & Leaves & Am73 & Ocotea elegans & Leaves \\
\hline Am 258 & Nectandra cuspidata & Branches & Am74 & Ocotea elegans & Branches \\
\hline M614 & Ocotea aciphylla & Branches & Am92 & O. paranapiacabensis & Leaves \\
\hline M809 & Ocotea odorifera & Branches & Am93 & O. paranapiacabensis & Fruits \\
\hline M823 & Ocotea velloziana & Leaves & Am94 & O. paranapiacabensis & Branches \\
\hline M849 & Ocotea odorifera & Leaves & Am245 & Ocotea corymbosa & Leaves \\
\hline R59 & Ocotea indecora & Leaves & Am246 & Ocotea corymbosa & Branches \\
\hline R60 & Ocotea indecora & Branches & Am447 & Ocotea teleiandra & Leaves \\
\hline $\mathrm{R} 172$ & Ocotea velutina & Leaves & Am448 & Ocotea teleiandra & Branches \\
\hline \multicolumn{6}{|c|}{ Moraceae } \\
\hline Am29 & Dorstenia arifolia & Branches & & & \\
\hline \multicolumn{6}{|c|}{ Nyctaginaceae } \\
\hline $\mathrm{R} 17$ & Bougainvillea sp. & Leaves & Am116 & Guapira oppositta & Leaves \\
\hline R18 & Bougainvillea sp. & Branches & Am117 & Guapira oppositta & Branches \\
\hline $\mathrm{R} 148$ & Pisonia ambigua & Leaves & Am202 & Guapira noxia & Leaves \\
\hline R149 & Pisonia ambigua & Branches & Am 203 & Guapira noxia & Branches \\
\hline
\end{tabular}




\begin{tabular}{|c|c|c|c|c|c|}
\hline \multicolumn{6}{|c|}{ Verbenaceae } \\
\hline M872 & Lantana undulata & Leaves & Am 270 & Lippia velutina & Leaves \\
\hline M873 & Lantana undulata & Branches & Am271 & Lippia velutina & Branches \\
\hline M943 & Starchytarpheta cayenensis & Leaves & Am371 & Lippia lupulina & Leaves \\
\hline M944 & Starchytarpheta cayenensis & Branches & Am372 & Lippia lupulina & Branches \\
\hline R297 & Lippia salviaefolia & Leaves & Am373 & Lippia lupulina & Flowers \\
\hline R298 & Lippia salviaefolia & Branches & & & \\
\hline
\end{tabular}

Table 2. Trypanocidal activity and cytotoxicity of families of the Brazilian flora against epimastigote forms of the $\mathrm{Y}$ strain of Trypanosoma cruzi and LLCMK 2 fibroblasts, respectively.

\begin{tabular}{|c|c|c|c|c|c|c|c|}
\hline N. Extract & Species & Family/part of the plant & IC50 $\mu \mathrm{g} / \mathrm{mL}$ & $\mathrm{CC} 50 \mu \mathrm{g} / \mathrm{mL}$ & SI & $\begin{array}{c}\text { Trypanocidal } \\
\text { activity }\end{array}$ & Cytotoxicity \\
\hline Am93 & Ocotea paranapiacabensis & Lauraceae/Fruits & 179.8 & 392.2 & 2.18 & Inactive & $\begin{array}{l}\text { Moderately } \\
\text { toxic }\end{array}$ \\
\hline R60 & Ocotea indecora & Lauraceae/Branches & 214.8 & 498.2 & 2.32 & Inactive & $\begin{array}{l}\text { Moderately } \\
\text { toxic }\end{array}$ \\
\hline Am160 & Aegiphila lhotzkiana & Lamiaceae/Fruits & 126.0 & 104.1 & 0.83 & Inactive & $\begin{array}{l}\text { Moderately } \\
\text { toxic }\end{array}$ \\
\hline Am116 & Guapira oppositta & Nyctaginaceae/Leaves & 386.4 & 115.9 & 0.30 & Inactive & $\begin{array}{l}\text { Moderately } \\
\text { toxic }\end{array}$ \\
\hline Am379 & Duguetia lanceolata & Annonaceae/Branches & 250.2 & 52.23 & 0.21 & Inactive & Toxic \\
\hline $\mathrm{Am} 03$ & Guatteria elliptica & Annonaceae/Branches & 345.1 & 103.3 & 0.30 & Inactive & $\begin{array}{l}\text { Moderately } \\
\text { toxic }\end{array}$ \\
\hline Am352 & Duguetia lanceolata & Annonaceae/Leaves & 157.9 & 332.4 & 2.11 & Inactive & $\begin{array}{c}\text { Moderately } \\
\text { toxic }\end{array}$ \\
\hline M1103 & Xylopia aromatica & Annonaceae/Fruits & 253.1 & 98.40 & 0.39 & Inactive & Toxic \\
\hline
\end{tabular}

Table 3. Trypanocidal activity and cytotoxicity of families of the Brazilian flora against epimastigote forms of the Bolivia strain of Trypanosoma cruzi and LLCMK 2 fibroblasts, respectively.

\begin{tabular}{|c|c|c|c|c|c|c|c|}
\hline N. Extract & Species & Family/part of the plant & IC50 $\mu \mathrm{g} / \mathrm{mL}$ & $\mathrm{CC} 50 \mu \mathrm{g} / \mathrm{mL}$ & SI & $\begin{array}{c}\text { Trypanocidal } \\
\text { activity }\end{array}$ & Cytotoxicity \\
\hline Am93 & Ocotea paranapiacabensis & Lauraceae/Fruits & 26.93 & 392.2 & 14.56 & Active & $\begin{array}{l}\text { Moderately } \\
\text { toxic }\end{array}$ \\
\hline Am73 & Ocotea elegans & Lauraceae/Leaves & 350.8 & 140.2 & 0.400 & Inactive & $\begin{array}{l}\text { Moderately } \\
\text { toxic }\end{array}$ \\
\hline Am160 & Aegiphila lhotzkiana & Lamiaceae/Fruits & 90.89 & 104.1 & 1.150 & $\begin{array}{l}\text { Moderately } \\
\text { active }\end{array}$ & $\begin{array}{l}\text { Moderately } \\
\text { toxic }\end{array}$ \\
\hline
\end{tabular}

\section{Results and Discussion}

Ninety-two ethanol extracts of different species of Brazilian flora were tested. The trypanocidal activity of the samples was classified according to criteria set by Osorio et al. (2007). The extracts were classified as highly active (IC50<10 $\mu \mathrm{g} / \mathrm{mL}$ ), active (IC50 $>10<50 \mu \mathrm{g} / \mathrm{mL}$ ), moderately active (IC50>50<100 $\mu \mathrm{g} / \mathrm{mL}$ ) and inactive (IC50>100 $\mu \mathrm{g} / \mathrm{mL}$ ). With regard to their cytotoxicity, the samples were classified as highly toxic (CC50<10 $\mu \mathrm{g}$ / $\mathrm{mL})$, toxic $(\mathrm{CC} 50>10<100 \mu \mathrm{g} / \mathrm{mL})$, moderately toxic $(\mathrm{CC} 50>100<1000 \mu \mathrm{g} / \mathrm{mL})$ and potentially non-toxic (CC50>1000 $\mu \mathrm{g} / \mathrm{mL})$.
According to this classification, all the 92 ethanol extracts tested against epimastigote forms of the $\mathrm{Y}$ strain of T. cruzi are inactive (Table 2).

Regarding the Bolivia strain, the fruit extract of Ocotea paranapiacabensis (Lauraceae) (Am93) is considered active, whereas the fruit extract of Aegiphila lhotzkiana (Lamiaceae) (Am160) and the leaf extract of Ocotea elegans (Am73) were respectively classified as moderately active and inactive against the same parasitic forms (Table 3 ).

The IC50 values for benznidazole against epimastigote forms of the $\mathrm{Y}$ and Bolivia strains were 0.99 and 11.77, respectively (Tables 2 and 3). 
Regarding the cytotoxicity analysis, the extracts of Duguetia lanceolata (Am379) and Xylopia aromatica (M1103) were classified as toxic to LLCMK 2 cells, whereas the extracts of Ocotea paranapiacabensis (Am93), Ocotea elegans (Am73), Ocotea indecora (R60), Aegiphila lhotzkiana (Am160), Guapira oppositta (Am116), Guatteria elliptica (Am03), and Duguetia lanceolata (Am352) were classified as moderately toxic (Tables 2 and 3).

The most promising samples were those that proved to be more active against epimastigote forms of $T$. cruzi and less toxic to $\mathrm{LLCMK}_{2}$ cells.

According to this classification, the most promising extracts for chemical and pharmacological investment were the fruit of Ocotea paranapiacabensis, Lauraceae (Am93), which proved to be active against epimastigote forms of the Bolivia strain and moderately toxic to LLCMK2 cells, its SI being equal to 14.56, and the fruit extract of Aegiphila lhotzkiana, Lamiaceae (Am160), which was also tested against the Bolivia strain and showed moderate activity regarding the parasites and the LLCMK2 cells.

By comparing the trypanocidal activity of the extracts against the $\mathrm{Y}$ strain and the Bolivia strain, a clear difference could be noted. The material tested against the Y strain did not show a satisfactory activity. On the other hand, two extracts (Am93 and Am160), which were tested against the Bolivia strain, were found to be, respectively, active and moderately active against such parasitic forms. This difference in sensitivity between the strains can be explained by the fact that $T$. cruzi populations show large intraspecific variability, as it can be noted by differences in their morphology, virulence, pathogenicity, evasion ability in case of an immune response from the host, antigenic composition and biochemical properties (Fernandes et al., 1998; Tibayrenc \& Ayala, 2002).

The trypanocidal activity of the ethanol extract of Ocotea paranapiacabensis (Lauraceae) against epimastigote forms of the Bolivia strain is reported for the first time in this work. Data from the literature report the activity of isolated alkaloids of Ocotea odorifera against promastigote forms of Leishmania braziliensis, L. donovan and L. amazonensis and trypomastigote forms of T. cruzi (Fournet et al., 2007). Extracts of branches and roots of the same species were found to be active against Plasmodium falciparum. Popular medicine recommends the use of these plants in the treatment for dermatoses, rheumatism, fever and syphilis (Botsaris, 2007).

Aegiphila lhotzkiana, which showed trypanocidal activity against the Bolivia strain, is widely distributed in Northeastern Brazil, where it is popularly known as paude-sebo. The oil obtained from its fruit is used in popular medicine for treating pediculosis and scabies, and its extract is used as an antidote to snakebite (Costa-Lotufo et al., 2004). The activity of this crude extract was unknown until this research was carried out, because there are no reports in the literature on the trypanocidal activity of this species, not even on the genus it belongs to.

The screening of Brazilian plants has indicated the potential effect of ethanol extracts obtained from fruits of Ocotea paranapiacabensis (Lauraceae) and Aegiphila lhotzkiana (Lamiaceae) against Chagas disease, considering the epimastigote forms of the Bolivia strain of T. cruzi.

These data reinforce the importance of the efforts to promote the sustainable use of Brazilian biodiversity, focusing on the search for new therapeutic agents for the treatment of some neglected diseases that affect millions of people in Brazil and other countries.

\section{Acknowledgments}

The authors want to thank Miriam P. A. Toldo, Mariana Rosa, Mariana Bryan Augusto and Isabel Martinez for helping in the laboratory procedures, and the BIOTA-FAPESP (03/02176-7) and BIOPROSPECTAFAPESP (04/07932) programs and the CNPq for the scholarships and resources granted.

\section{References}

Bastos JK, Albuquerque S, Silva MLA 1999. Evaluation of the trypanocidal activity of lignans isolated from the leaves of Zanthoxylum naranjillo. Planta Med 65: 1-4.

Batista JM Jr, Lopes AA, Ambrósio DL, Regasini LO, Kato MJ, Bolzani VS, Cicarelli RM, Furlan M 2008. Natural chromenes and chromene derivatives as potencial antitrypanosomal agents. Biol Pharm Bull 31: 538-540.

Botsaris A 2007. Plants used traditionally to treat malaria in Brazil: the archives of Flora Medicinal. J Ethnobiol Ethnomed 1: 18.

Buainain A, Giazzi JF, Belda Neto FM, Martini AS, Rosa, JA, Pozetti, GL 1992. Estudo da atividade de extratos vegetais sobre o desenvolvimento de Trypanosoma cruzi em meio líquido de Warren. Rev Cien Farm 14: 93-102.

Cabral MM, Barbosa-Filho JM, Maia GL, Chaves MC, Braga MV, De Souza W 2010. Neolignans from plants in northeastern Brazil (Lauraceae) with activity against Trypanosoma cruzi. Exp Parasitol 124: 319-324.

Costa-Lotufo LV, Silveira ER, Barros MC, Lima MA, De Moraes ME, De Moraes MO, Pessoa C 2004. Antiproliferative effects of abietane diterpenes from Aegiphilla lhotzkyana. Planta Med 70: 180-182.

Cotinguiba F, Regasini LO, Bolzani VS, Debonsi HM, Passerini DO, Cicarelli RMB, Kato MJ, Furlan M 2009. Piperamides and their derivatives as potential antitrypanosomal agents. Med Chem Res 18: 703-711.

Coura JR, Castro SL 2002. A critical review on Chagas disease chemotherapy. Mem I Oswaldo Cruz 97: 3-24. 
Coura JR 2009. Present situation and new strategies for Chagas disease chemotherapy: a proposal. Mem I Oswaldo Cruz 104: 549-554.

Fernandes O, Souto RP, Castro JA, Pereira JB, Fernandes NC, Junqueira AC, Naiff RD, Barrett TV, Degrave W, Zingales B, Campbell DA, Coura JR 1998. Brazilian isolates of Trypanosoma cruzi from humans and triatomines classified into two lineages using mini-exon and ribosomal RNA sequences. Am J Trop Med Hyg 58: 807-811.

Fournet A, Ferreira ME, Rojas de Arias A, Guy I, Guinaudeau H, Heinzen H 2007. Phytochemical and antiprotozoal activity of Ocotea lancifolia. Fitoterapia 78: 382-384.

Lopes AA, López SN, Regasini LO, Batista-Jr. JM, Ambrósio DL, Kato MJ, da Silva Bolzani V, Cicarelli RM, Furlan M 2008. In vitro activity of compounds isolated from Piper crassinervium against Trypanosoma cruzi. Nat Prod Res 22: 1040-1046.

Macedo AM, Oliveira RP, Pena SDJ 2002. Chagas disease: role of parasite genetic variation in pathogenesis. Exp Mol Med 4: 1-16.

Muelas-Serrano S, Nogal-Ruiz JJ, Gómez-Barrio A 2000. Setting of a colorimetric method to determine the viability of Trypanosoma cruzi epimastigotes. Parasitol Res 86: 999-1002.

Nwaka S, Ridley RG 2003. Virtual drug discovery and development for neglected diseases through publicprivate partnerships. Nat Rev Drug Discov 2: 919-928.
Osorio E, Arango GJ, Jiménez N, Alzate F, Ruiz G, Gutiérrez D, Paco MA, GiménezA, Robledo S 2007. Antiprotozoal and cytotoxic activities in vitro of Colombian Annonaceae. $J$ Ethnopharmacol 111: 630-635.

Regasini LO, Cotinguiba F, Passerini GD, Bolzani VS, Cicarelli RMB, Kato MJ, Furlan M 2009. Trypanocidal activity of Piper arboreum and Piper tuberculatum (Piperaceae). Rev Bras Farmacog 19: 199-203.

Saraiva J, Vega C, Rolon M, da Silva R, Silva, ML, Donate PM, Bastos JK, Gomez-Barrio A, de Albuquerque S 2007. In vitro and in vivo activity of lignan lactones derivatives against Trypanosoma cruzi. Parasitol Res 100: 791-795.

Tibayrenc M, Ayala FJ 2002. The clonal theory of parasitic protozoa: 12 years on. Trends Parasitol 18: 405-410.

World Health Organization 2010. http://www.who.int/ mediacentre/factsheets/fs340/en/index.html, accessed in Aug 2010.

\section{*Correspondence}

Renata Tomé Alves

Faculdade de Ciências Farmacêuticas de Araraquara, Universidade Estadual Paulista, Departamento de Ciências Biológicas, Laboratório de Parasitologia

Rodovia Araraquara/Jau, km1, 14801-902 Araraquara-SP, Brazil rosaja@fcfar.unesp.br

Tel.: +551633016943

Fax: +551633016940 